\title{
Testing of composite beam with demountable shear connectors
}

1 Naveed Rehman MEng (Hons)

PhD Candidate, School of Engineering, University of Bradford, Bradford, UK

2 Dennis Lam BEng, MPhil, PhD, CEng, MICE, FIStructE, MASCE Chair in Structural Engineering \& Director of Bradford Centre for Sustainable Environments, School of Engineering, University of Bradford, Bradford, UK (corresponding author: d.lam1@bradford.ac.uk)
3 Xianghe Dai BEng, MSc, PhD, CEng, MIStructE, FHEA Senior Lecturer in Structural Engineering, School of Engineering, University of Bradford, Bradford, UK

4 Ashraf Ashour BSc (Hons), MSc, PhD, CEng, FIStructE, FHEA Professor of Structural Engineering, School of Engineering, University of Bradford, Bradford, UK
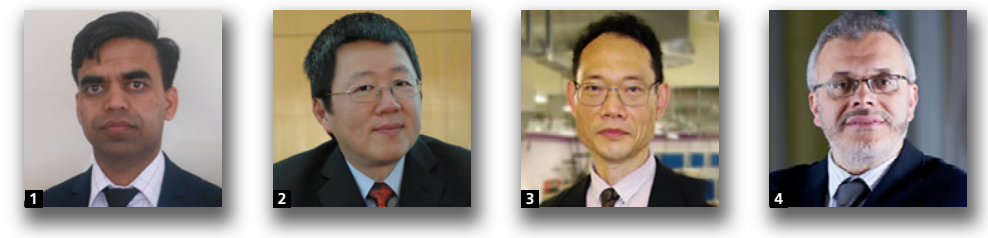

An experimental study on an innovative composite floor system that can be demounted and deconstructed is described. In this system, the composite slab, formed with profiled metal decking, was connected to a steel beam by way of demountable shear connectors. A full-scale demountable composite floor system (DCFS) was tested to ultimate load-bearing capacity and compared with a similar non-demountable composite floor system specimen using conventional welded headed stud connectors. The experimental results and observations showed that the structural behaviour and load-bearing capacity of both composite floor systems were very similar. However, the composite floor system with demountable shear connectors could be deconstructed after testing and the composite slab could be easily detached from the steel beam. The comparison and analysis presented in this paper indicate that the simple design methods currently provided in Eurocode 4 for welded shear connections could be used to assess the ultimate moment capacity of DCFSs.

\section{Notation}

$A_{\text {a }}$

$a$

$B_{\text {e }}$

$B_{\text {eff }}$

$d$

E

$E_{\mathrm{cm}}$

$F_{B_{\mathrm{f}}}$

$F_{B_{\mathrm{w}}}$

$F_{\text {c }}$

$F_{T_{\mathrm{f}}}$

$F_{T_{\mathrm{w}}}$

$f_{\mathrm{ck}}$

$f_{\mathrm{u}}$

$f_{\mathrm{y}}$

$h_{\mathrm{a}}$

$h_{\mathrm{p}}$

$h_{\mathrm{s}}$

$I_{\mathrm{a}}$

$I_{\text {comp }}$ cross-sectional area of steel section distance from support to point load effective breadth of concrete flange effective breadth of concrete flange of composite beam

diameter of shear connector embedded in concrete modulus of elasticity of structural steel mean modulus of elasticity of concrete forces in bottom steel flange forces in bottom half of steel web maximum force in concrete slab forces in top steel flange forces in upper half of steel web characteristic cylinder strength of concrete at $28 \mathrm{~d}$ ultimate tensile strength of shear connector yield strength of structural steel height of steel section height of profiled steel sheeting excluding embossments height of composite slab second moment of area of structural steel section second moment of area of composite section with full shear connection
$K$

$k_{\mathrm{t}}$

$L$

$l$

$M_{\mathrm{Pl}, \mathrm{a}, \mathrm{Rd}}$

$M_{\mathrm{Pl}, \mathrm{Rd}}$

$M_{\mathrm{Rd}}$

$M_{\mathrm{u}}$

$N_{\mathrm{a}}$

$N_{\mathrm{c}}$

$N_{\text {c,f }}$

$P_{\text {rd }}$

$P_{\mathrm{t}}$

$P_{\mathrm{u}}$

WL

$w_{\mathrm{Pl}, \mathrm{y}}$

$\alpha$

$\alpha_{\mathrm{e}}$

$\delta_{\mathrm{c}}$ stiffness of shear connector reduction factor for resistance of headed stud used with profiled steel sheeting transverse to beam composite beam span span of composite floor beam plastic resistance moment of structural steel section plastic resistance moment of composite section with full shear connection resistance moment of composite section ultimate moment capacity normal force in structural steel section of composite beam normal force in shear connectors normal force in concrete flange with full shear connection shear resistance of single connector point load ultimate load working load plastic modulus of steel section about the major axis shear connector's height coefficient modular ratio of steel to concrete deflection of composite beam with full shear connection 


$\begin{array}{ll}\delta_{\text {partial }} & \begin{array}{l}\text { deflection of composite beam with partial } \\ \text { shear connection }\end{array} \\ \delta_{\mathrm{s}} & \text { deflection of steel beam } \\ \varepsilon & \text { strain } \\ \eta & \begin{array}{l}\text { degree of shear connection of composite beam at } \\ \text { ultimate limit state } \\ \end{array} \\ \sigma & \text { stress }\end{array}$

\section{Introduction}

Composite structures are widely used in building constructions due to their enhanced stiffness and superior load-carrying capacity. In current practice, composite action is achieved by welding shear connectors to a steel beam through the decking before concreting. This process makes it almost impossible to separate the concrete slab from the steel beam when the structure comes to the end of its design life, meaning that structural components such as steel beams and composite concrete slabs cannot be reused. Although the steel beam may be recycled, the recycling process consumes a massive amount of energy and generates a large volume of carbon dioxide emissions. Over recent years, more sustainable building techniques have been considered and recommended in the construction industry to reduce waste and reuse materials more efficiently without recycling. Therefore, demountability of construction systems, especially composite flooring systems, is very important as it allows structural parts to be reused without the need for recycling.

Published works on demountable shear connectors are limited. However, high-strength bolts embedded in solid concrete slabs were tested through push-off tests by Dallam (1968), and it was reported that high-strength bolted connectors had about twice the load shear capacity than welded shear connectors. Marshall et al. (1971) investigated high-strength grip bolts in solid concrete slabs using the push-out technique, but the framework was not very clear in their research work.

Moynihan and Allwood (2014) tested a Gr 8.8 M20 bolted shear connector in composite beam tests. The embedded nut was used to attach metal decking to a steel beam flange and the test results were comparable to the results from composite beams with welded headed studs. Mirza et al. (2010) studied blind bolts in composite structures and observed that their behaviour was relatively brittle as compared to welded connectors. Kwon et al. (2010) extended the research of Schaap (2004), but the focus of their research was to investigate the performance of post-installed bolted shear connectors under fatigue loading and demountability was not considered.

Most researchers used the post-installation method or the use of embedded nuts to investigate the behaviour of high-strength bolted shear connectors in composite construction. However, through push-off tests and finite-element analysis, Lam and Saveri (2012) and Dai et al. (2015) investigated the behaviour of demountable shear connectors without embedded nuts in solid reinforced concrete slabs to assess their potential and suitability in terms of replacing welded headed shear connectors. Rehman et al. (2016) investigated the behaviour of different types of demountable connectors with and without an embedded nut in metal decking composite slabs and concluded that demountable shear connectors can be used instead of welded shear connectors in metal decking concrete slabs without using embedded nuts. However, it appears that the structural behaviour of a full-scale composite beam with profiled metal decking utilising demountable connectors without embedded nuts has not yet been reported.

The research presented in this paper investigated the structural behaviour and demountability of a demountable composite floor system (DCFS) using demountable shear connectors through experimental testing. Two companion push-off tests were also carried out to study the load-slip behaviour and ultimate strength of demountable shear connectors under static shear loading. An identical composite floor system using welded shear connectors (referred to here as a welded composite floor system (WCFS)) was also tested for comparison purposes. The experimental results highlighted the potential of DCFSs using demountable shear connectors.

\section{Experimental study}

\subsection{Details of test specimens}

Two full-scale experiments were conducted on a WCFS with conventional welded shear connectors (Figure 1) and a DCFS with demountable shear connectors (Figure 2). The

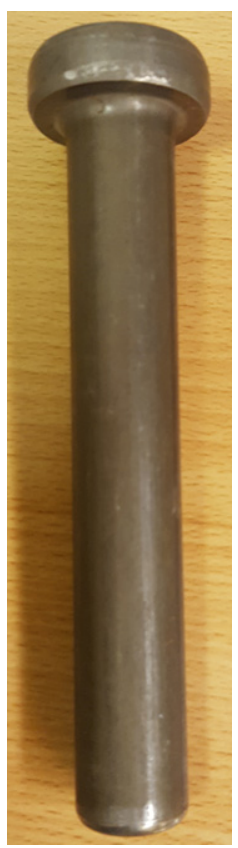

Figure 1. Conventional shear connector used in WCFS specimen 


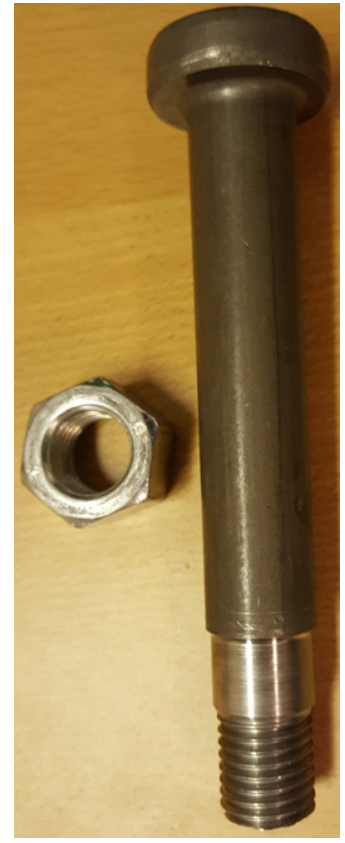

Figure 2. Demountable shear connector detail

demountable shear connector, with a $17 \mathrm{~mm}$ collar and a $16 \mathrm{~mm}$ threaded portion, was fabricated using a normal T.W. Nelson shear connector. The other components of the tested specimens were composite concrete slabs with a profiled metal deck, a steel beam and steel reinforcement. Details of the specimens are given in Table 1 .

\subsubsection{DCFS specimen}

The steel beam was set as a simply supported beam with a span of $5 \cdot 2 \mathrm{~m}$ and profiled metal decking was laid down on the steel beam. The demountable shear connectors were

\section{Table 1. Details of test specimens}

$\begin{array}{ll}\text { Total length of steel beam } & 5600 \mathrm{~mm} \\ \text { Span length between supports, I } & 5200 \mathrm{~mm} \\ \text { Steel section } & \text { IPE300 } \\ \text { Thickness of steel flange, } t_{\mathrm{f}} & 10.7 \mathrm{~mm} \\ \text { Thickness of steel web, } t_{\mathrm{w}} & 7 \cdot 1 \mathrm{~mm} \\ \text { of steel beam, } W_{\text {Ply }} & 602 \mathrm{~cm}^{3} \\ \text { Cross-sectional area, } A_{\mathrm{a}} & 53.80 \mathrm{~cm}^{2} \\ \text { Yield strength of steel beam, } f_{\mathrm{y}} & 410 \mathrm{MPa} \\ \text { Concrete compressive cube strength } & 37 \mathrm{MPa} \\ \text { Distance between point load and support, a } & 1900 \mathrm{~mm} \\ \text { Width of composite concrete floor, } B_{\mathrm{e}} & 1340 \mathrm{~mm} \\ \text { Overall depth of composite concrete slab, } h_{\mathrm{s}} & 130 \mathrm{~mm} \\ \text { Metal profiled decking } & \text { Cofraplus } 60 \\ \text { Position of reinforcement mesh } & \text { Top of metal } \\ & \text { decking } \\ \text { Height of metal decking } & 58 \mathrm{~mm} \\ \text { Number of connectors } & 26 \\ \text { Trough spacing } & 207 \mathrm{~mm} \\ \text { Reinforcement mesh type } & \text { A142 (standard) }\end{array}$

installed through pre-drilled holes in the profiled metal decking and steel beam flange to assemble the specimen, as shown in Figure 3. The diameter of the pre-drilled holes in the steel beam flange was $18 \mathrm{~mm}$, which provided a clearance of $1 \mathrm{~mm}$ between the connector collar and the hole. The nuts were tightened up to $60 \mathrm{~N}$.m using a torque wrench to ensure all the demountable shear connecters were equally installed. Standard A142 mesh reinforcement was used in the concrete slab. The composite floor beam system was designed with a partial shear connection and a single shear connector was adopted in each trough of the profiled metal decking. The connectors were placed in a staggered position along the longitudinal direction of the steel beam. The height of the shear connectors was $100 \mathrm{~mm}$ and the diameter was $19 \mathrm{~mm}$ inside the concrete. The collar diameter of the shear connector was $17 \mathrm{~mm}$ passing through the metal deck and steel flange and the threaded portion was $16 \mathrm{~mm}$ to match the M16 nut. Detailed layouts are presented in Figures 3 and 4.

The composite floor beam was propped during casting but the props were removed immediately after casting to simulate un-propped construction. The specimen was cured for $28 \mathrm{~d}$ before the loading test. The concrete strength was determined by taking the average strength of cubes cast from the same concrete as the slab and tested on the same day as the main composite beam test. The mean compressive cube strength of the concrete was determined to be $37 \mathrm{MPa}$.

\subsubsection{WCFS specimen}

An identical composite floor beam system with conventional welded shear connectors was also constructed and tested to compare the structural behaviour of composite systems using demountable shear connectors and welded shear connectors. The dimensions were the same as those of the DCFS, as presented in Table 1 and Figures 3 and 4. The WCFS specimen also had the same steel beam section size (IPE300), Cofraplus 60 profiled metal decking and $19 \mathrm{~mm}$ diameter shear connectors, A142 mesh reinforcement and concrete mix design. The only difference between the two specimens was the type of shear connectors.

\subsubsection{Test setup and instrumentation}

The DCFS specimen was tested under a two-point loading system, as shown in Figures 5 and 6. The vertical downward load was applied by a $1000 \mathrm{kN}$ hydraulic jack and the load was distributed by means of a spreader beam. Eleven linear variable displacement transducers (LVDTs) were installed to measure the end slip, vertical deflection and relative slippage between the steel beam and the concrete slab.

As shown in Figure 7, 13 strain gauges were installed on the steel beam and three strain gauges were installed at the concrete slab surface to measure the strains in the concrete and the steel beam. A central computer-controlled logging system was used to record all data. 


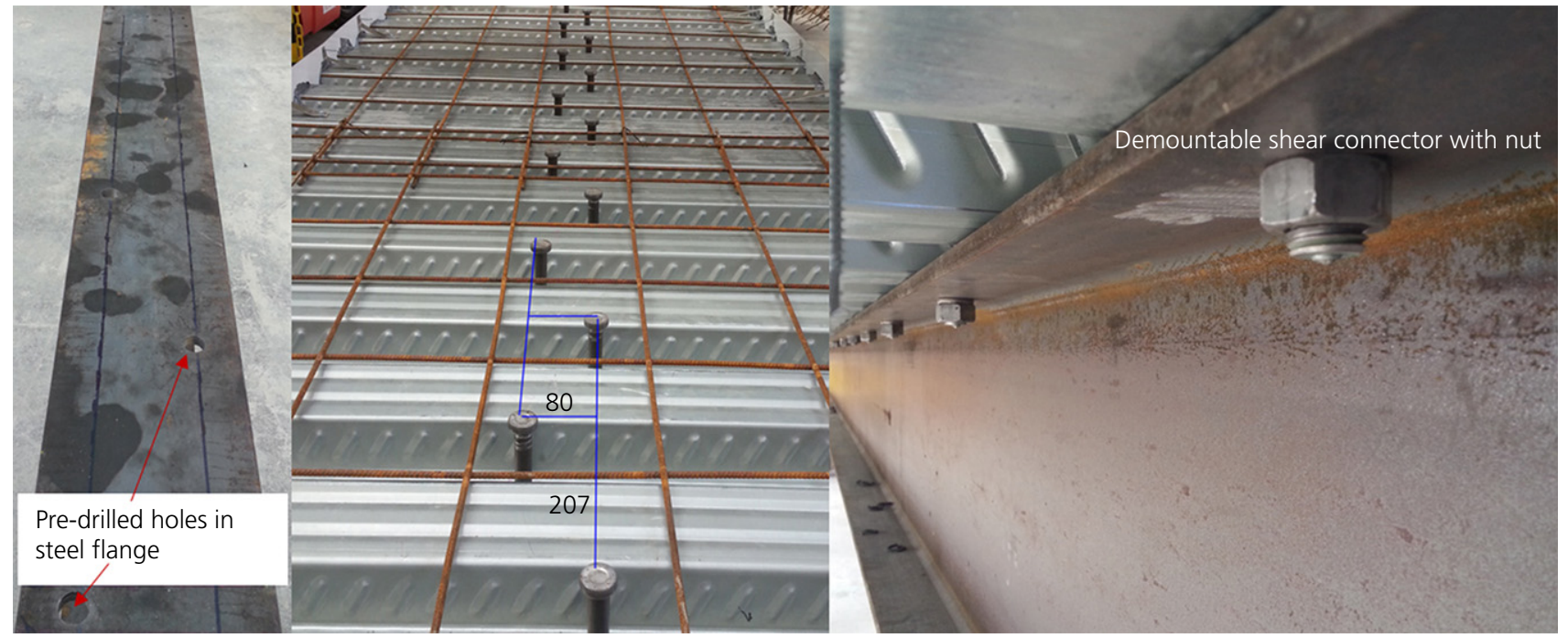

Figure 3. Assembled DCFS specimen and staggered positions of predrilled holes in steel flange and layout before casting (dimensions in $\mathrm{mm}$ )

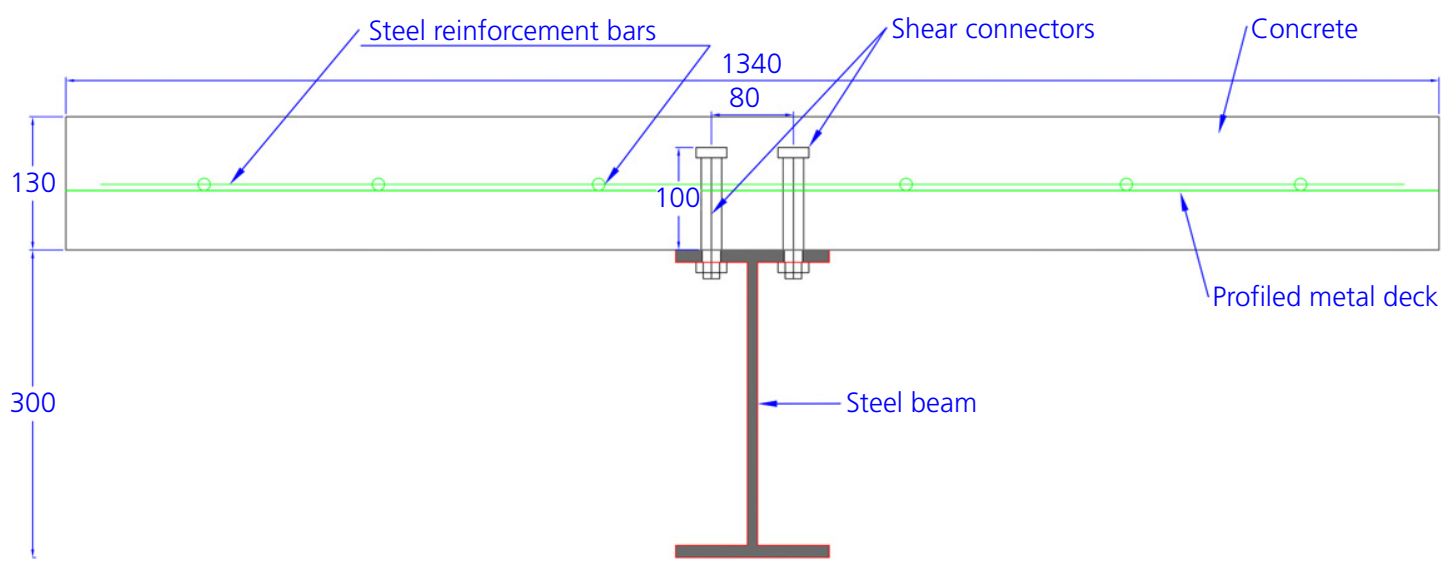

Figure 4. Cross-sectional view of DCFS test specimen (dimensions in $\mathrm{mm}$ )

\subsubsection{Loading}

The DCFS and WCFS specimens were tested under similar loading conditions (Figure 5). The hydraulic jack, LVDTs and strain gauges were calibrated before the start of the test. Four different static loading regimes were used to test the specimens under loading and unloading cycles. The load was applied at a constant rate of $5 \mathrm{kN} / \mathrm{min}$. The first loading regime was to observe the behaviour of the specimen under a normal working load (WL) of $5 \mathrm{kN} / \mathrm{m}^{2}$ and the specimen was unloaded once the targeted load was reached. This loading was repeated for four cycles $(\mathrm{C} 1-\mathrm{C} 4)$ for the DCFS specimen to examine any initial slip and deflection due to the clearance holes between the shear connectors and the holes in the steel flange. The second loading (C5) and third loading (C6) were $1.5 \mathrm{WL}\left(7.5 \mathrm{kN} / \mathrm{m}^{2}\right)$ and $3 \mathrm{WL}\left(15 \mathrm{kN} / \mathrm{m}^{2}\right)$, respectively.
Finally, the specimen was loaded to its ultimate capacity (C7), which was about $9 \mathrm{WL}$.

\subsection{Companion push-off tests}

\subsubsection{Description of push-off test specimens and test setup}

Two companion push-off specimens were tested to assess the shear connector capacity of the demountable shear connector. As shown in Figure 8, the push-off test specimens consisted of a steel section $203 \times 203 \times 52 \mathrm{UB}$, a concrete composite slab with metal profiled decking and steel reinforcement bars of $10 \mathrm{~mm}$ diameter. A single demountable shear connector (shown in Figure 2) was positioned in the centre of each trough of the profiled metal decking with staggered positions, 


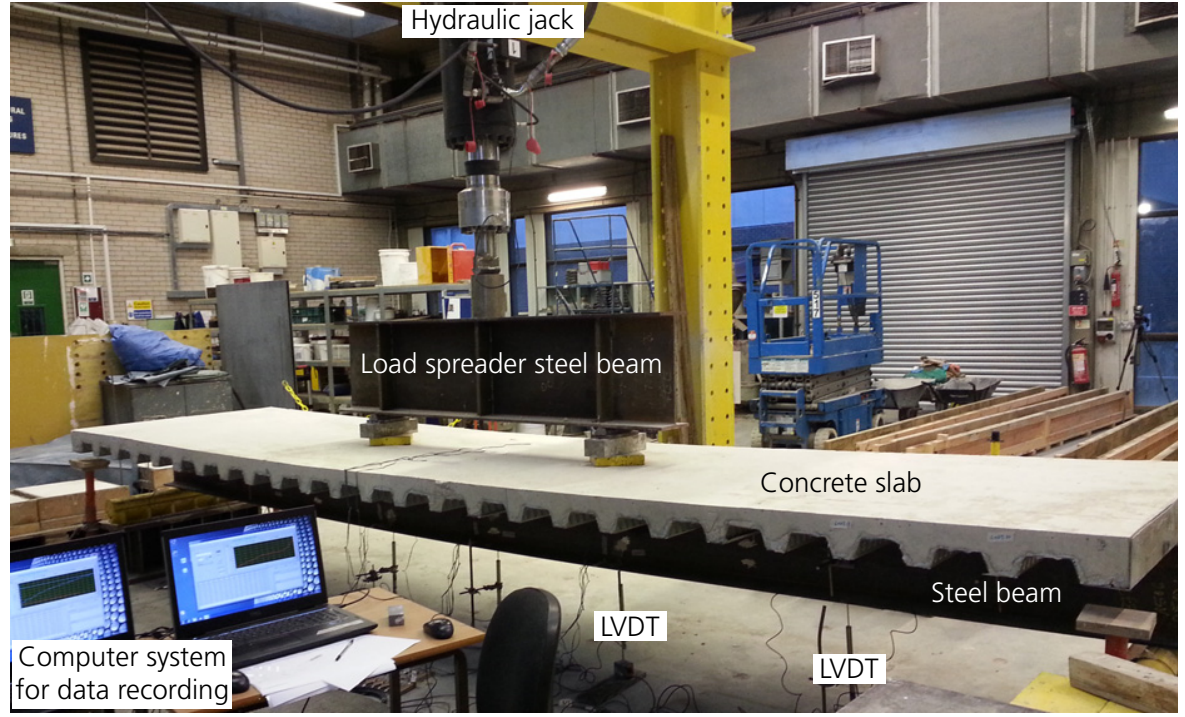

Figure 5. Test setup of DCFS specimen

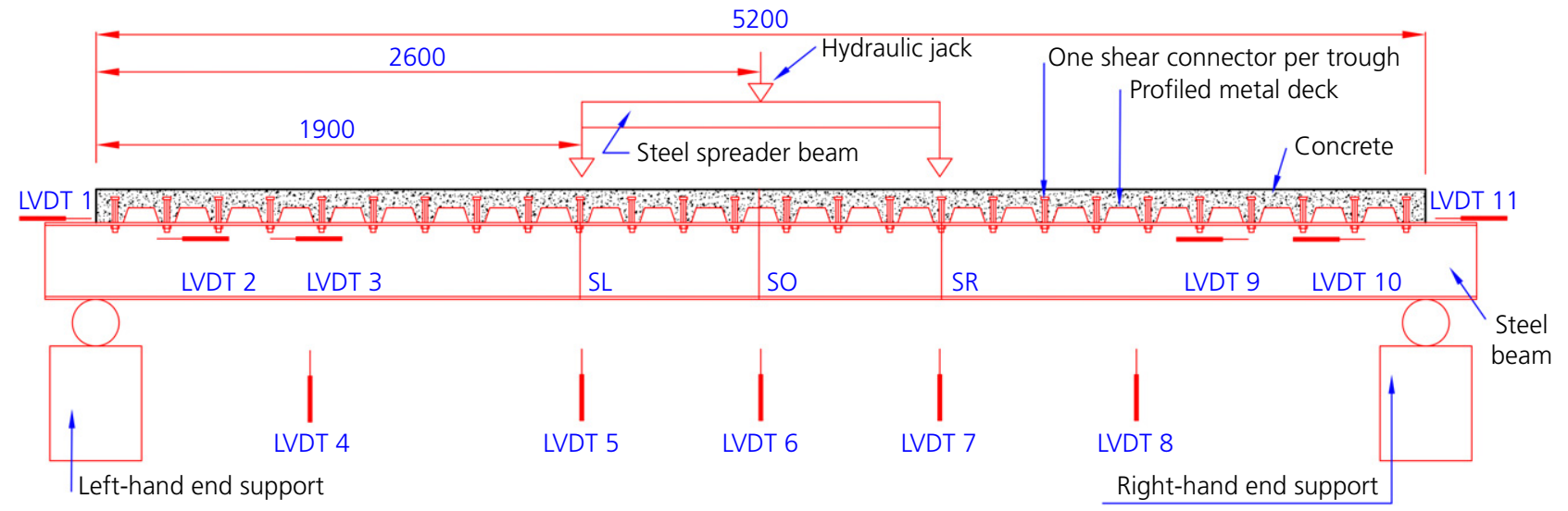

Figure 6. Test layout and positions of instrumentation (dimensions in $\mathrm{mm}$ )

as utilised in DCFS beam specimen. Cofraplus 60 profiled metal decking, as used in the beam test, was also used for the push-off test specimens. Eight LVDTs were installed at the top of the steel beam and concrete slabs to measure the vertical displacements, as shown in Figure 9. These measurements were subsequently used to calculate the relative slip between the steel beam and the concrete slab.

\subsubsection{Loading procedure}

A hydraulic jack was used to apply load vertically downward on the top of the steel section. During the test, the applied load was increased by $5 \mathrm{kN} / \mathrm{min}$ until it reached $40 \%$ of the predicted failure load based on the Eurocode 4 (CEN, 2004) equation $\left(P_{\mathrm{rd}}=\min \quad\left(0 \cdot 29 \alpha k_{\mathrm{t}} d^{2}\left(f_{\mathrm{ck}} \mathrm{E}_{\mathrm{cm}}\right)^{1 / 2}, \quad 0 \cdot 8 k_{\mathrm{t}} \mathrm{f}_{\mathrm{u}}\left(\pi \mathrm{d}^{2} / 4\right)\right)\right)$. Then, the loading rate was decreased to $2 \mathrm{kN} / \mathrm{min}$. This was to observe the plateau of the load-slip curve until failure of specimen and to avoid any sudden failure.

\section{Experimental results and discussion}

\subsection{Composite floor beam test results}

Table 2 lists the ultimate applied loads and moment capacities of the DCFS and the WCFS (the ultimate loads do not include the self-weight of the composite beam and the spreader beam). Initially, the specimens were loaded to $5 \mathrm{kN} / \mathrm{m}^{2}$ and then unloaded. They were then further loaded up to $7 \cdot 0 \mathrm{kN} / \mathrm{m}^{2}$ and $15 \mathrm{kN} / \mathrm{m}^{2}$ and unloaded. This loading regime was undertaken to ensure that the specimen was in the elastic region in the initial loading regimes. After this, the load was increased statically by increments of $1 \mathrm{kN} / \mathrm{m}^{2}$ to avoid any sudden failure until the ultimate load capacity was achieved. 


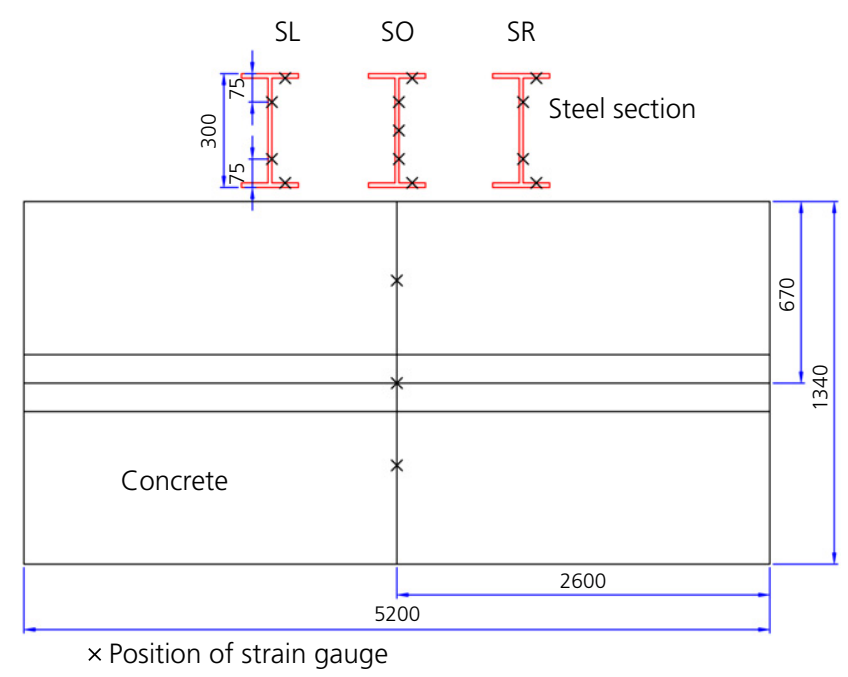

Figure 7. Positions of strain gauges on steel beam and concrete slab (dimensions in $\mathrm{mm}$ )

The imposed failure loads were recorded as $340.54 \mathrm{kN}$ and $338 \cdot 12 \mathrm{kN}$ for the DCFS and WCFS specimens, respectively. If the self-weight of the concrete composite slab, spreader steel beam and steel beam are taken into account in the DCFS test specimen, the total failure load becomes $359 \cdot 2 \mathrm{kN}$. Considering a global safety factor of $2 \cdot 5$, the un-factored load becomes $143.68 \mathrm{kN}$. This load-bearing capacity of $143.68 \mathrm{kN}$ was achieved well before the start of plastic deformation of the DCFS test specimen.

\subsection{Push-off test results}

Table 3 shows the results of the push-off tests. The average shear capacity of the demountable shear connectors was about $39 \mathrm{kN}$ per connector, which was used to determine the shear capacity and degree of shear connection in the composite beam test. Figure 10 shows the load-slip behaviour of the two push-off tests, indicating very ductile behaviour and showing that the limit of $6 \mathrm{~mm}$ for ductile behaviour according to Eurocode 4 was fulfilled. A concrete cone failure mode was observed in the two push-off tests, which was possibly due to the smaller effective width of the decking trough.

\subsection{Load-deflection behaviour of composite floor systems}

Figure 11 shows that the load-deflection behaviours of the DCFS and WCFS test specimens were very similar. The midspan deflection of the DCFS specimen reached $80 \mathrm{~mm}$ (more than span/70) at ultimate load, showing that the DCFS specimen exhibited excellent ductility. The load-deflection curve was almost linear up to $70 \%$ of the ultimate load $\left(P_{\mathrm{u}}\right)$, as illustrated in Figure 11.

Very similar load-bearing capacities were observed in both specimens. However, the specimen with demountable shear connectors demonstrated better ductility - about $30 \%$ higher than that of the specimen with conventional welded shear connectors. The initial stiffness of the DCFS specimen was lower than that of the WCFS specimen. This low initial stiffness might result from oversized holes in the steel flange, which

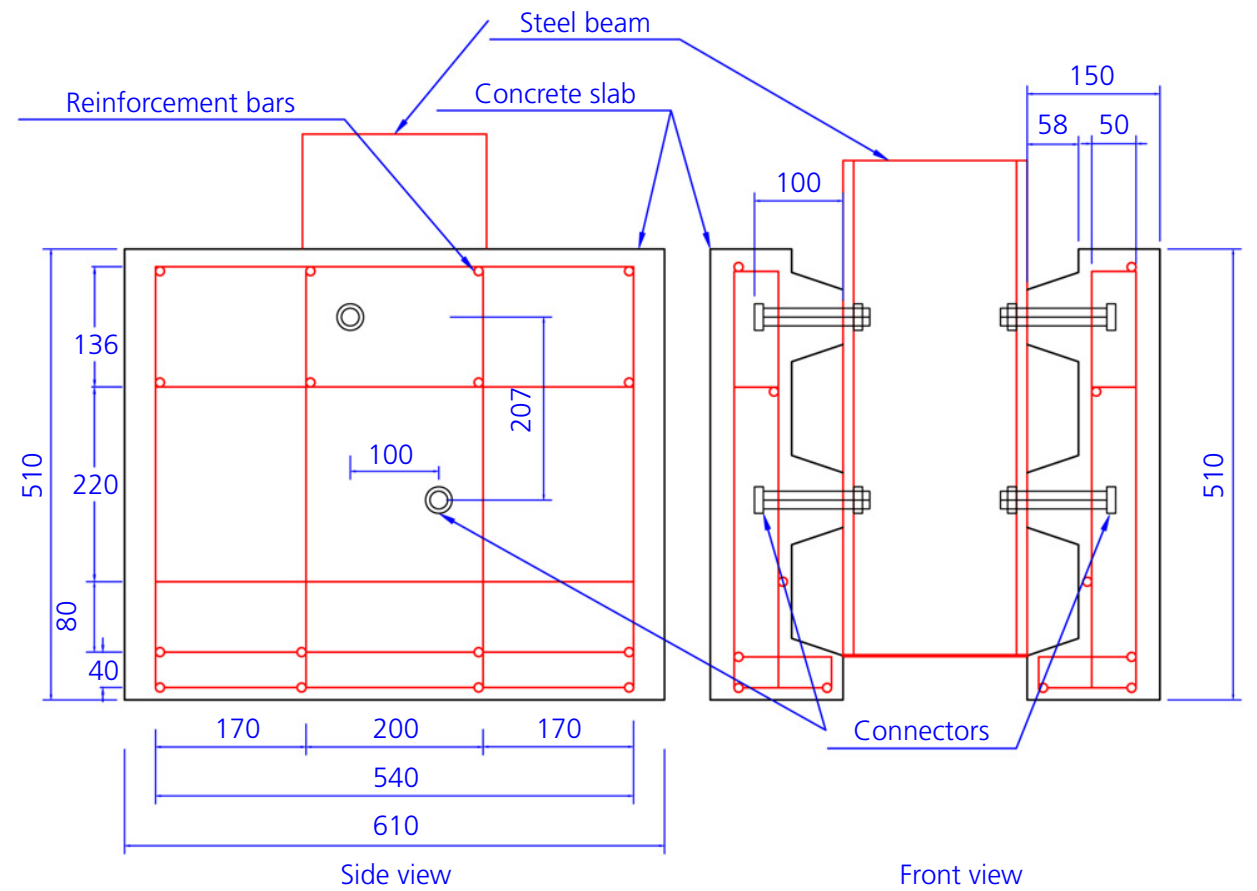

Figure 8. Push-off test detail 
Testing of composite beam with

demountable shear connectors

Rehman, Lam, Dai and Ashour

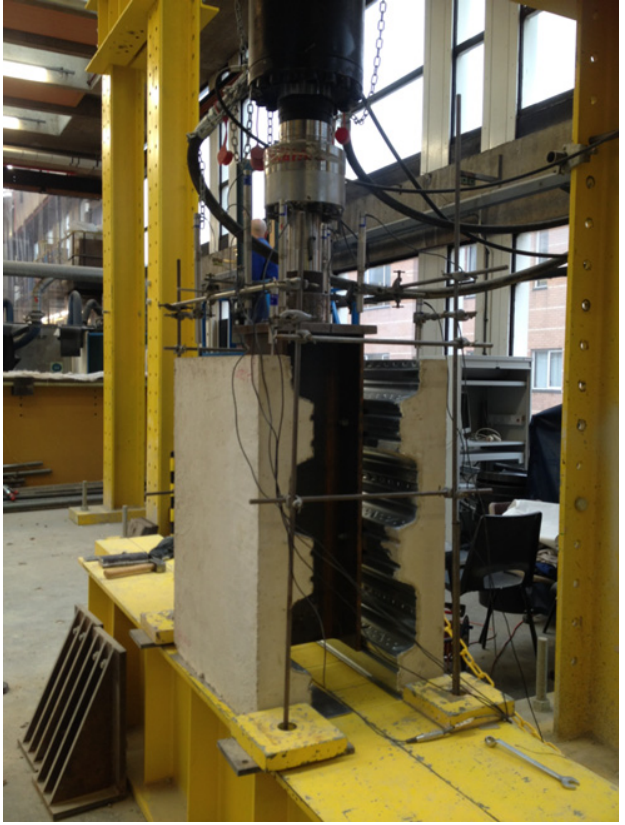

Figure 9. Push-off test setup

Table 2. Test results of composite floor systems

\begin{tabular}{|lcccc|}
\hline & $\begin{array}{c}\text { Concrete } \\
\text { strength: } \\
\text { MPa }\end{array}$ & $\begin{array}{c}\text { Total } \\
\text { ultimate } \\
\text { load: } \mathbf{k N}\end{array}$ & $\begin{array}{c}\text { Ultimate } \\
\text { deflection: } \\
\text { mm }\end{array}$ & $\begin{array}{c}\text { Moment } \\
\text { capacity: } \\
\text { kN.m }\end{array}$ \\
\hline DCFS & 37 & $340 \cdot 54$ & $81 \cdot 10$ & $323 \cdot 5$ \\
WCFS & 36 & $338 \cdot 12$ & $59 \cdot 11$ & $321 \cdot 2$ \\
\hline
\end{tabular}

caused a larger initial slip between the steel beam and the composite slab. The initial stiffness could possibly be increased by tightening the connectors with a higher torque.

The mid-span deflections at different loading cycles of the DCFS specimen are shown in Figure 12. The maximum midspan deflection and residual deflection against a uniformly distributed load obtained from the test are given in Table 4. It can be seen that a residual deflection of $0.6 \mathrm{~mm}$ was observed under the first cycle of the working load. This was caused by the clearance holes in the steel flange and no further residual deflection was observed when the same working loading was repeated. The residual deflection increased gradually with an increase in load. The deflection at three times the working load was less than span/500, which indicates the capacity of low residual deflection in the DCFS. The overall residual deflection of the DCFS specimen was about $66 \%$ higher than that observed in the WCFS specimen. This could be due to the possible effect of oversized holes or nut tightening forces.

\subsection{Load-slip behaviour of the composite beam}

The load-slip behaviour at both ends of the DCFS specimen is presented in Figure 13. More than $6 \mathrm{~mm}$ of slip was recorded at both ends, which fulfils the Eurocode 4 requirement of ductility for welded shear connectors. Under the first cycle of the normal working load, an average end slip of $0.09 \mathrm{~mm}$ on the left-hand end and $0 \cdot 14 \mathrm{~mm}$ on the right-hand end were observed. After four cycles of the working load, the residual end slip was less than $0.25 \mathrm{~mm}$. This clearly indicates a low degree of end slip at the working load. The maximum end slips and residual slips for the specimen under the various loading conditions are given in Table 5. It can be seen that the end slip and the residual slip increased gradually with an increase in load. The load-end slip behaviour was almost linear up to $60 \%$ of the ultimate load at both ends of the DCFS specimen, as shown in Figure 13.

The slips between the steel beam and the metal deck slab at the positions of the second (LVDT 2) and fourth shear connectors (LVDT 3) are presented in Figure 14. It can be seen that both connectors showed very similar behaviour. The slip at the position of the second connector was slightly higher than that at the fourth connector. An initial slip of about $0.1 \mathrm{~mm}$ was observed for both connectors under the first cycle of the normal working load.

Tables 6 and 7 show the maximum relative slips and residual slips between the steel decking and the steel beam top flange at the positions of the second and fourth shear connectors of the specimen from the end supports. The residual slip after unloading was between $0 \cdot 18 \mathrm{~mm}$ and $0.21 \mathrm{~mm}$ on both sides after being loaded to three times the working load. The initial slip observed in the DCFS specimen was about $70 \%$ higher than that in the WCFS specimen. The overall initial residual slip in the DCFS was about $52 \%$ higher than that in the WCFS specimen. The larger slip observed in the DCFS specimen was possibly due to tolerance between the shear connector collar and holes.

\subsection{Strain distribution in the concrete and steel beam}

The measured strains at the mid-span section (S0) of the steel beam and the concrete slab against each cycle of the loading regime are listed in Table 8 . A strain value of $2000 \mu \varepsilon$ or higher was considered as equivalent to the yield strength of a steel section of $410 \mathrm{MPa}$. The steel section and concrete slab were completely in the elastic region up to three times the

Table 3. Test results of push-off specimens

\begin{tabular}{|lcccc} 
& Concrete strength: MPa & Load per connector: $\mathbf{k N}$ & Slip at maximum load: $\mathbf{m m}$ & Slip at failure: $\mathbf{m m}$ \\
\hline Push-off test 1 & 37 & $39 \cdot 2$ & $11 \cdot 60$ \\
Push-off test 2 & 36 & 38.5 & $11 \cdot 20$
\end{tabular}




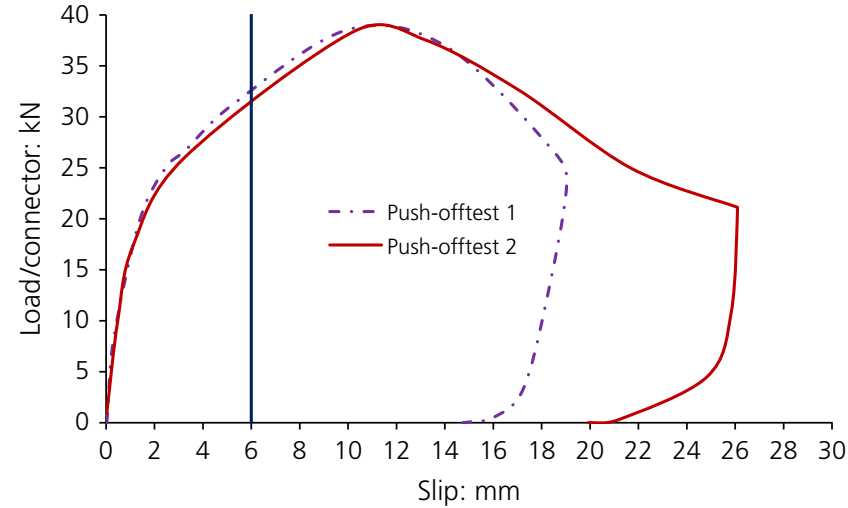

Figure 10. Load-slip behaviour in push-off tests and Eurocode 4 limit of $6 \mathrm{~mm}$

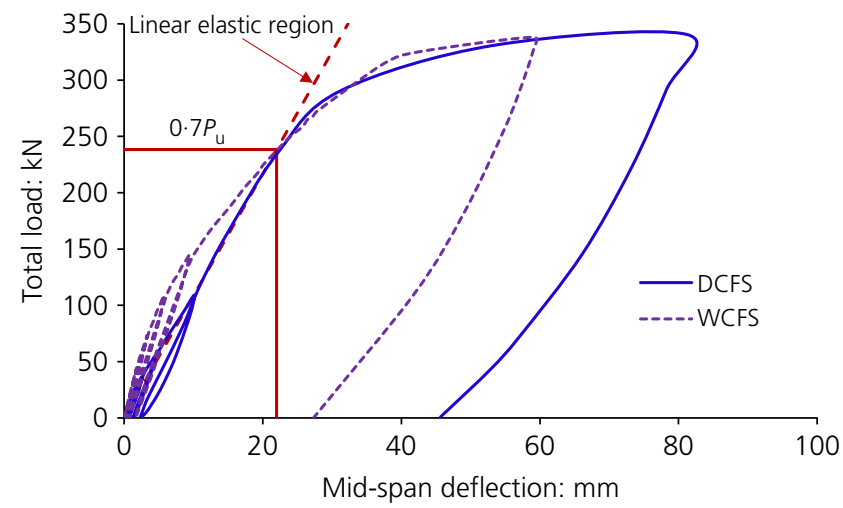

Figure 11. Load-mid-span deflection of DCFS and WCFS beam tests

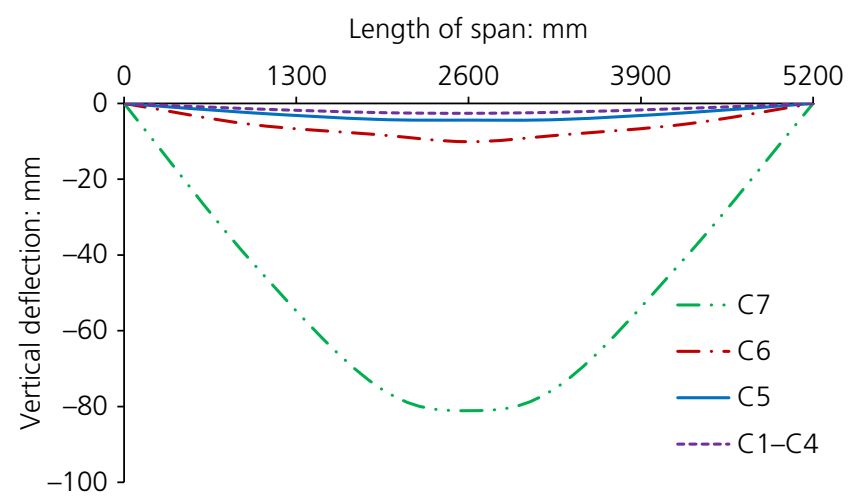

Figure 12. Deflection of DCFS beam test at different loading cycles

working load, as can be seen from the strain values in Table 8 . At the ultimate load, the steel bottom flange completely yielded and the strain values reached $8969 \mu \varepsilon$. The compressive strain of the top flange reached $1487 \mu \varepsilon$ and the neutral axis was in the upper half of the steel web when the specimen was loaded up to ultimate capacity. This indicates good composite action between the steel beam and the composite concrete slab using demountable shear connectors at three times the working load and ultimate load. The typical compressive strain recorded in the concrete slab at maximum load was $925 \mu \varepsilon$ $(0.092 \%)$, which is well below the strain of $2000 \mu \varepsilon(0.2 \%)$ usually experienced by concrete at its maximum strength.

\subsection{Mode of failure}

No major failure was observed during testing of the DCFS specimen. The test was terminated when the steel beam was fully yielded, as seen from strain value given in Table 8 . There was no indication of failure of a demountable shear connector or a nut. Cracks were visible on the top surface of the slab in the longitudinal direction of the beam. No major cracks were detected on the side edges of the concrete slab. There was no evidence of deck separation or concrete pull-out during the test. There was some evidence of uplifting of the composite slab at the middle section after unloading the specimen at the end of the test.

\subsection{Comparison and analysis of stiffness, moment capacity and deflection}

\subsubsection{Stiffness}

The overall stiffness of the DCFS specimen was comparable to that of the WCFS specimen but the initial stiffness of the DCFS specimen was about $67 \%$ lower than that of the WCFS specimen. This low initial stiffness might result from the oversized hole in the steel flange, which caused a larger initial slip between the steel beam and the composite slab. This could be reduced by tightening the nut with a higher torque. The stiffnesses at $40 \%$ of the ultimate load of the DCFS and WCFS specimens were $80.09 \mathrm{kN} / \mathrm{mm}$ and $243.9 \mathrm{kN} / \mathrm{mm}$, respectively, as shown in Figures 15 and 16. The stiffnesses of both specimens were almost equal at about $84 \%$ of the ultimate load.

\subsubsection{Rigid plastic analysis}

The moment capacity of the composite beam was calculated using rigid plastic theory through the rectangular stress blocks and the interpolation method for the concrete slab and the steel beam in accordance with clause 6.2.1.2 of Eurocode 4 (CEN, 2004) at the mid-span of the composite beam.

\subsubsection{CALCULATION OF MOMENT OF RESISTANCE USING STRESS BLOCKS}

From the push-off tests, the shear capacity of a single shear connector was found to be approximately $39 \mathrm{kN}$. This value was used to determine the degree of shear connection $(\eta)$ in the composite beam using Equations 1-3.

1. $\quad \eta=\frac{N_{\mathrm{c}}}{\min \left(N_{\mathrm{a}}, N_{\mathrm{c}, \mathrm{f}}\right)}$ 
Table 4. Deflection at mid-span of DCFS specimen

\begin{tabular}{lcccc} 
& $\begin{array}{c}\text { Working load, WL } \\
\text { (C1-C4) }\end{array}$ & $\begin{array}{c}\mathbf{1 . 5 W L} \\
\text { (C5) }\end{array}$ & $\begin{array}{c}\text { 3WL } \\
\text { (C6) }\end{array}$ & $\begin{array}{c}\text { Ultimate load } \\
\text { (C7) }\end{array}$ \\
\hline Load: $\mathrm{kN} / \mathrm{m}^{2}$ & $5 \cdot 0$ & $7 \cdot 5$ & $15 \cdot 0$ & $48 \cdot 87$ \\
Deflection at maximum load in each loading cycle: $\mathrm{mm}$ & $2 \cdot 6$ & 3.8 & $8 \cdot 8$ & $78 \cdot 8$ \\
Residual deflection: $\mathrm{mm}$ & 0.6 & 0.8 & 1.0 & $43 \cdot 26$ \\
Cumulative residual deflection: $\mathrm{mm}$ & 0 & 0.6 & $1 \cdot 3$ & $2 \cdot 3$ \\
Cumulative deflection at maximum loading: $\mathrm{mm}$ & $2 \cdot 6$ & $4 \cdot 4$ & $10 \cdot 1$ & $81 \cdot 1$
\end{tabular}

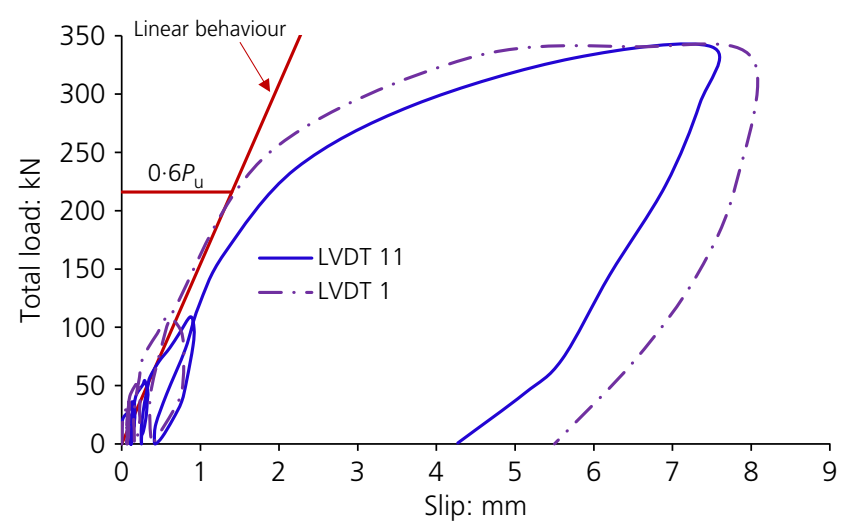

Figure 13. Load-slip behaviour at LVDT 1 (left-hand end) LVDT 11 (right-hand end) of DCFS specimen

2. $N_{\mathrm{c}, \mathrm{f}}=0.85 \times f_{\mathrm{ck}} \times B_{\text {eff }} \times\left(h_{\mathrm{s}}-h_{\mathrm{p}}\right)$

3. $N_{\mathrm{a}}=f_{\mathrm{y}} \times A_{\mathrm{a}}$

where $N_{\mathrm{a}}$ is the tensile capacity of the steel section, $N_{\mathrm{c}}(=10 \times 39 \mathrm{kN})$ is the shear resistance of shear connectors in a shear span and $N_{\mathrm{c}, \mathrm{f}}$ is the capacity of compression force in concrete. The other parameters are defined in the notation.

The effect of the reinforcement and profiled metal decking was ignored to simplify the calculations. The calculation of the ultimate moment resistance of the composite beam was based on the plastic neutral axis (PNA). The PNA was worked out by balancing the forces in the concrete slab and the steel section. The values of strain $(\varepsilon)$ shown in Figure 17 were used to work out the stresses $(\sigma)$ in the steel top flange and the upper half of the web $\left(T_{\mathrm{w}}\right)$ as these parts of the steel section have not yielded. Equations 4 and 5 were considered to work out the forces in these parts of the steel section. The values of stresses in the bottom half of the web and bottom flange parts were considered fully yielded. Young's modulus $(E)$ of the steel section was assumed to be $210 \mathrm{GPa}$. Equation 6 presents the forces in the concrete slab due to partial shear connection. The ultimate moment capacity was worked out through Equation 7 and using the PNA as a centre line of equilibrium.

4. $\quad$ Stress $=\frac{\text { Force }}{\text { Area }}$

5. $E=\frac{\sigma}{\varepsilon}$

6. $F_{\mathrm{c}}=\eta \times\left(h_{\mathrm{s}}-h_{\mathrm{p}}\right) \times b_{\mathrm{eff}} \times f_{\mathrm{ck}}$

$$
\begin{aligned}
M_{\mathrm{u}}= & F_{\mathrm{c}}\left(\frac{h_{\mathrm{s}}}{2}+t_{\mathrm{f}}+T_{\mathrm{w} 1}\right)+F_{T_{\mathrm{f}}}\left(\frac{t_{\mathrm{f}}}{2}+T_{\mathrm{w} 1}\right) \\
& +F_{T_{\mathrm{w} 1}}\left(\frac{T_{\mathrm{w} 1}}{2}\right)+F_{T_{\mathrm{w} 2}}\left(\frac{T_{\mathrm{w} 2}}{2}\right) \\
& +F_{B_{\mathrm{w}}}\left(T_{\mathrm{w} 2}+\frac{B_{\mathrm{w}}}{2}\right)+F_{B_{\mathrm{f}}}\left(\frac{t_{\mathrm{f}}}{2}+T_{\mathrm{w} 2}+B_{\mathrm{w}}\right)
\end{aligned}
$$

where $M_{\mathrm{u}}$ is the ultimate moment capacity, $F_{\mathrm{c}}$ is the force in concrete, $B_{\text {eff }}$ is the effective width of concrete, $F_{T_{\mathrm{f}}}, F_{T_{\mathrm{w} 1}}$ and $F_{T_{\mathrm{w} 2}}, F_{B_{\mathrm{w}}}$ and $F_{B_{\mathrm{f}}}$ are the forces in the steel top flange, the top web $\left(T_{\mathrm{w}}\right)$, the bottom web $\left(B_{\mathrm{w}}\right)$ and the bottom flange respectively. The height of the upper half of the web and bottom half of the web is represented by $T_{\mathrm{w}}$ and $B_{\mathrm{w}}$, respectively. $T_{\mathrm{w} 1}$ is the height of the web part from the PNA to the top flange and $T_{\mathrm{w} 2}$ is the height of the web from PNA to the centre line (CL) of the steel beam. $B_{\mathrm{w}}$ is the height of the web from the centre line of the steel beam to the bottom flange. The thickness of the flange is $t_{\mathrm{f}}$ and the thickness of the web is $t_{\mathrm{w}}$.

\subsubsection{CALCULATION OF MOMENT OF RESISTANCE USING INTERPOLATION METHOD}

The moment resistance of the composite floor system was worked out using Equations 8-10.

8. $\quad M_{\mathrm{Rd}}=M_{\mathrm{Pl}, \mathrm{a}, \mathrm{Rd}}+\left(M_{\mathrm{Pl}, \mathrm{Rd}}-M_{\mathrm{Pl}, \mathrm{a}, \mathrm{Rd}}\right) \times \eta$ 
Table 5. Summary of end slips of DCFS specimen

\begin{tabular}{|c|c|c|c|c|}
\hline & $\begin{array}{c}\text { WL } \\
\text { (C1-C4) }\end{array}$ & $\begin{array}{l}1.5 \mathrm{WL} \\
\text { (C5) }\end{array}$ & $\begin{array}{l}3 W L \\
\text { (C6) }\end{array}$ & $\begin{array}{l}\text { Ultimate load } \\
\text { (C7) }\end{array}$ \\
\hline Load: $\mathrm{kN} / \mathrm{m}^{2}$ & $5 \cdot 0$ & $7 \cdot 5$ & $15 \cdot 0$ & $48 \cdot 87$ \\
\hline Slip at each loading cycle LVDT 1: mm & 0.09 & $0 \cdot 14$ & 0.42 & $6 \cdot 19$ \\
\hline Residual slip LVDT 1: mm & 0.07 & 0.09 & 0.23 & $5 \cdot 01$ \\
\hline Cumulative residual slip LVDT 1: mm & $0 \cdot 0$ & 0.07 & $0 \cdot 16$ & 0.39 \\
\hline Cumulative slip by LVDT 1: mm & 0.09 & 0.21 & 0.58 & $6 \cdot 58$ \\
\hline End slip at each loading cycle LVDT 11: mm & $0 \cdot 14$ & $0 \cdot 19$ & 0.65 & $6 \cdot 91$ \\
\hline Residual slip LVDT 11: mm & $0 \cdot 11$ & $0 \cdot 12$ & 0.26 & $3 \cdot 87$ \\
\hline Cumulative residual slip LVDT 11: mm & 0.0 & 0.11 & 0.23 & 0.49 \\
\hline Cumulative slip by LVDT 11: mm & $0 \cdot 14$ & $0 \cdot 30$ & 0.88 & $7 \cdot 40$ \\
\hline
\end{tabular}

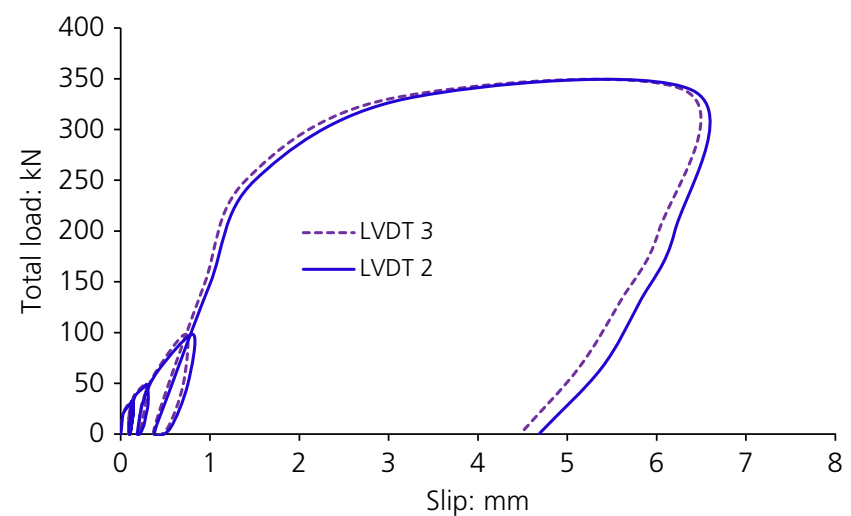

Figure 14. Load-slip behaviour of second (LVDT 2) and fourth (LVDT 3) connectors at left-hand end of DCFS specimen

where $M_{\mathrm{Rd}}$ is the moment resistance of the composite beam at partial shear connection, $M_{\mathrm{Pl}, \mathrm{a}, \mathrm{Rd}}$ is the moment capacity of the steel beam, $M_{\mathrm{Pl}, \mathrm{Rd}}$ is the moment capacity at full shear connection and $\eta$ is the degree of shear connection.

9. $\quad M_{\mathrm{Pl}, \mathrm{Rd}}=N_{\mathrm{a}}\left(h_{\mathrm{s}}+\frac{h_{\mathrm{a}}}{2}-\frac{N_{\mathrm{a}}}{N_{\mathrm{c}, \mathrm{f}}} \frac{h_{\mathrm{s}}-h_{\mathrm{p}}}{2}\right)$

10. $M_{\mathrm{Pl}, \mathrm{a}, \mathrm{Rd}}=f_{\mathrm{y}} \times w_{\mathrm{Ply}}$

The variables $h_{\mathrm{a}}, h_{\mathrm{s}}$ and $h_{\mathrm{p}}$ represent the height of the steel section, thickness of the concrete slab and the height of the profiled metal decking, respectively.

Comparisons of the experimental ultimate moments and those calculated using the stress block method and the interpolation method are shown in Table 9. The prediction of moment capacities from both methods is conservative compared with the experimental results, and both methods could be applicable for the design of a DCFS. The moment value obtained from the stress block method was about 3\% higher than the value obtained using the linear interpolation method. The ultimate moment calculated using the interpolation method is about $5 \%$ less than the experimental moment resistance. This indicates that the experimental value is very close to the value predicted by the stress block method and this method could thus be used for this type of composite construction.

\subsubsection{Deflection at mid-span}

The second moment of area $\left(I_{\mathrm{a}}\right)$ of the steel beam (IPE300) is $79.98 \times 10^{6} \mathrm{~mm}^{4}$. The second moment of area of the composite section was worked out using Equation 11 with a modular ratio $\alpha_{\mathrm{e}}=6$, and was calculated to be $320.08 \times 10^{6} \mathrm{~mm}^{4}$. The vertical deflection of the composite floor system under twopoint loading was determined from Equation 12.

$$
\begin{aligned}
\text { 11. } I_{\text {comp }}= & I_{\mathrm{a}}+\frac{B_{\mathrm{e}}\left(h_{\mathrm{s}}-h_{\mathrm{p}}\right)^{3}}{12 \alpha_{\mathrm{e}}} \\
& +\frac{A_{\mathrm{a}} B_{\mathrm{e}}\left(h_{\mathrm{s}}-h_{\mathrm{p}}\right)\left(h_{\mathrm{a}}+h_{\mathrm{s}}+h_{\mathrm{p}}\right)^{2}}{4\left[A_{\mathrm{a}} \alpha_{\mathrm{e}}+B_{\mathrm{e}}\left(h_{\mathrm{s}}-h_{\mathrm{p}}\right)\right]}
\end{aligned}
$$

12. $\delta_{\mathrm{c}}=\frac{P_{\mathrm{t}} a\left(3 l^{2}-4 a^{2}\right)}{24 E I_{\mathrm{comp}}}$

where $B_{\mathrm{e}}$ is the effective width of the slab, $A_{\mathrm{a}}$ is the area of the steel section, $l$ is the span of the composite floor beam, $a$ is the distance of the point load from the end support and $P_{\mathrm{t}}$ is point load.

The deflection of the composite beam was also worked out using BS 5950-3.1:1990+A1:2010 (BSI, 2010), which provides a method (Equation 13) for predicting the deflection of a composite beam with partial shear connections in propped construction for welded shear connectors.

13. $\delta_{\text {partial }}=\delta_{\mathrm{c}}+0 \cdot 5(1-\eta)\left(\delta_{\mathrm{s}}-\delta_{\mathrm{c}}\right)$ 
Table 6. Slip behaviour at second (LVDT 2) and fourth (LVDT 3) connector at left-hand end

\begin{tabular}{lcccc} 
& $\begin{array}{c}\text { WL } \\
\text { (C1-C4) }\end{array}$ & $\begin{array}{c}\mathbf{1 . 5 W L} \\
\text { (C5) }\end{array}$ & $\begin{array}{c}\text { 3WL } \\
\text { (C6) }\end{array}$ & $\begin{array}{c}\text { Ultimate load } \\
\text { (C7) }\end{array}$ \\
\hline Load: kN/m & 5.0 & 7.5 & 15.0 & 48.87 \\
Slip at each loading cycle LVDT 2: mm & 0.1 & 0.13 & 0.69 & 6.03 \\
Residual slip LVDT 2: mm & 0.09 & 0.11 & 0.26 & 5.1 \\
Cumulative residual slip LVDT 2: mm & 0.0 & 0.09 & 0.20 & 0.46 \\
Cumulative slip by LVDT 2: mm & 0.1 & 0.22 & 0.79 & 6.47 \\
End slip at each loading cycle LVDT 3: mm & 0.09 & 0.14 & 0.56 & 7.6 \\
Residual slip LVDT 3: mm & 0.08 & 0.1 & 0.21 & 4.96 \\
Cumulative residual slip LVDT 3: mm & 0.0 & 0.08 & 0.18 & 0.39 \\
Cumulative slip by LVDT 3: mm & 0.09 & 0.22 & 0.74 & 7.99
\end{tabular}

Table 7. Slip at second (LVDT 10) and fourth (LVDT 9) connectors at right-hand end

\begin{tabular}{|c|c|c|c|c|}
\hline & $\begin{array}{c}\text { WL } \\
\text { (C1-C4) }\end{array}$ & $\begin{array}{l}1.5 \mathrm{WL} \\
\text { (C5) }\end{array}$ & $\begin{array}{l}3 \mathrm{WL} \\
(\mathrm{C} 6)\end{array}$ & $\begin{array}{l}\text { Ultimate load } \\
\text { (C7) }\end{array}$ \\
\hline Load: $\mathrm{kN} / \mathrm{m}^{2}$ & $5 \cdot 0$ & $7 \cdot 5$ & $15 \cdot 0$ & 48.87 \\
\hline Slip at each loading cycle LVDT 9: mm & $0 \cdot 13$ & $0 \cdot 15$ & 0.31 & $5 \cdot 95$ \\
\hline Residual slip LVDT 9: mm & $0 \cdot 10$ & $0 \cdot 10$ & 0.75 & $5 \cdot 13$ \\
\hline Cumulative residual slip LVDT 9: mm & $0 \cdot 0$ & $0 \cdot 10$ & $0 \cdot 20$ & 0.95 \\
\hline Cumulative slip by LVDT 9: mm & $0 \cdot 13$ & 0.25 & 0.51 & $6 \cdot 90$ \\
\hline End slip at each loading cycle LVDT 10: mm & $0 \cdot 13$ & $0 \cdot 17$ & $0 \cdot 39$ & $6 \cdot 10$ \\
\hline Residual slip LVDT 10: mm & $0 \cdot 11$ & $0 \cdot 10$ & $0 \cdot 15$ & $6 \cdot 10$ \\
\hline Cumulative residual slip LVDT 10: mm & $0 \cdot 0$ & $0 \cdot 11$ & 0.21 & $0 \cdot 36$ \\
\hline Cumulative slip by LVDT 10: mm & $0 \cdot 13$ & $0 \cdot 28$ & 0.60 & $6 \cdot 46$ \\
\hline
\end{tabular}

Table 8. Measured strains in steel beam and top of concrete slab

\begin{tabular}{|c|c|c|c|c|}
\hline & $\begin{array}{c}\text { WL } \\
\text { (C1-C4) }\end{array}$ & $\begin{array}{l}1 \cdot 5 \mathrm{WL} \\
\text { (C5) }\end{array}$ & $\begin{array}{l}3 \mathrm{WL} \\
\text { (C6) }\end{array}$ & $\begin{array}{c}\text { Ultimate load } \\
\text { (C7) }\end{array}$ \\
\hline Load: kN/m² & $5 \cdot 0$ & $7 \cdot 5$ & $15 \cdot 0$ & 48.87 \\
\hline Average strain in concrete: $\mu \varepsilon$ & $-53 \cdot 2$ & $-89 \cdot 4$ & $-203 \cdot 5$ & $-925 \cdot 0$ \\
\hline Strain in steel beam top flange: $\mu \varepsilon$ & $5 \cdot 0$ & $-23 \cdot 6$ & $-150 \cdot 9$ & $-1487 \cdot 0$ \\
\hline Strain in upper part of web: $\mu \varepsilon$ & $12 \cdot 9$ & $26 \cdot 3$ & $33 \cdot 6$ & $50 \cdot 0$ \\
\hline Strain in middle of web: $\mu \varepsilon$ & $92 \cdot 3$ & $126 \cdot 6$ & $206 \cdot 9$ & $1850 \cdot 0$ \\
\hline Strain in lower part of web: $\mu \varepsilon$ & $143 \cdot 5$ & $211 \cdot 0$ & $424 \cdot 6$ & $6570 \cdot 0$ \\
\hline Strain in steel beam bottom flange: $\mu \varepsilon$ & $190 \cdot 6$ & $287 \cdot 5$ & $615 \cdot 2$ & $8969 \cdot 0$ \\
\hline
\end{tabular}

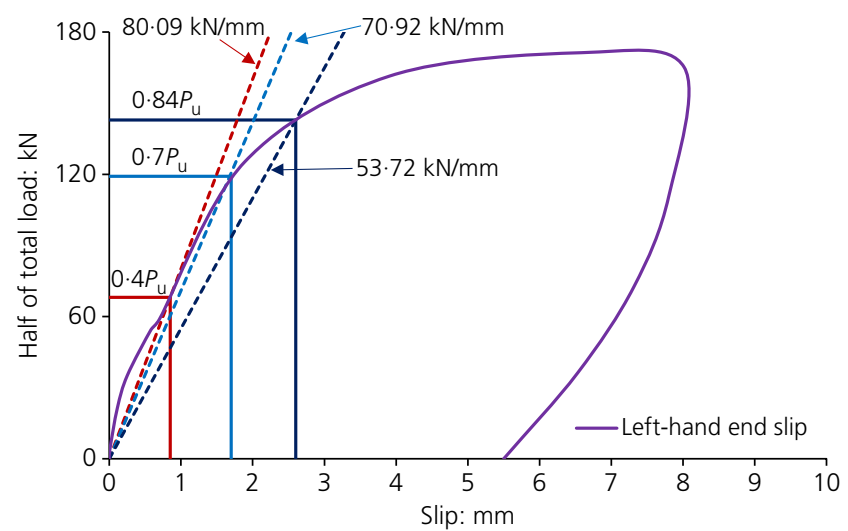

Figure 15. Initial stiffness of DCFS specimen

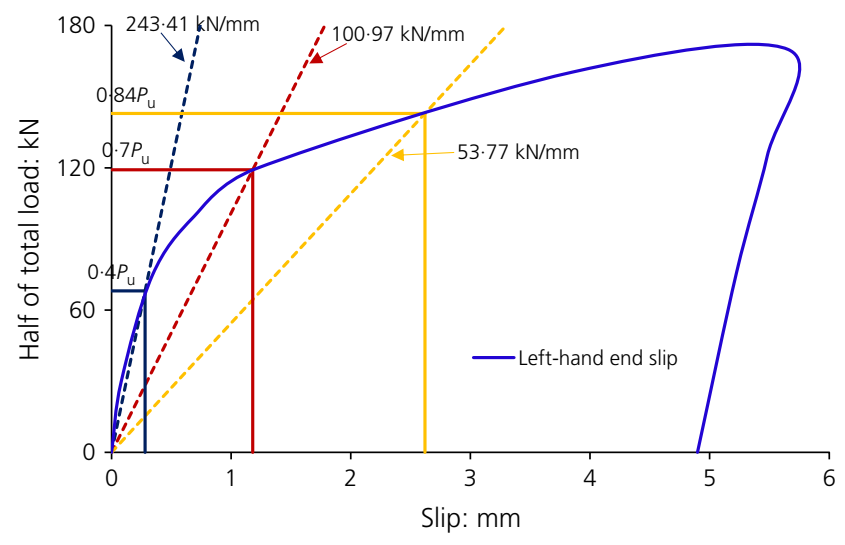

Figure 16. Stiffness of WCFS specimen 

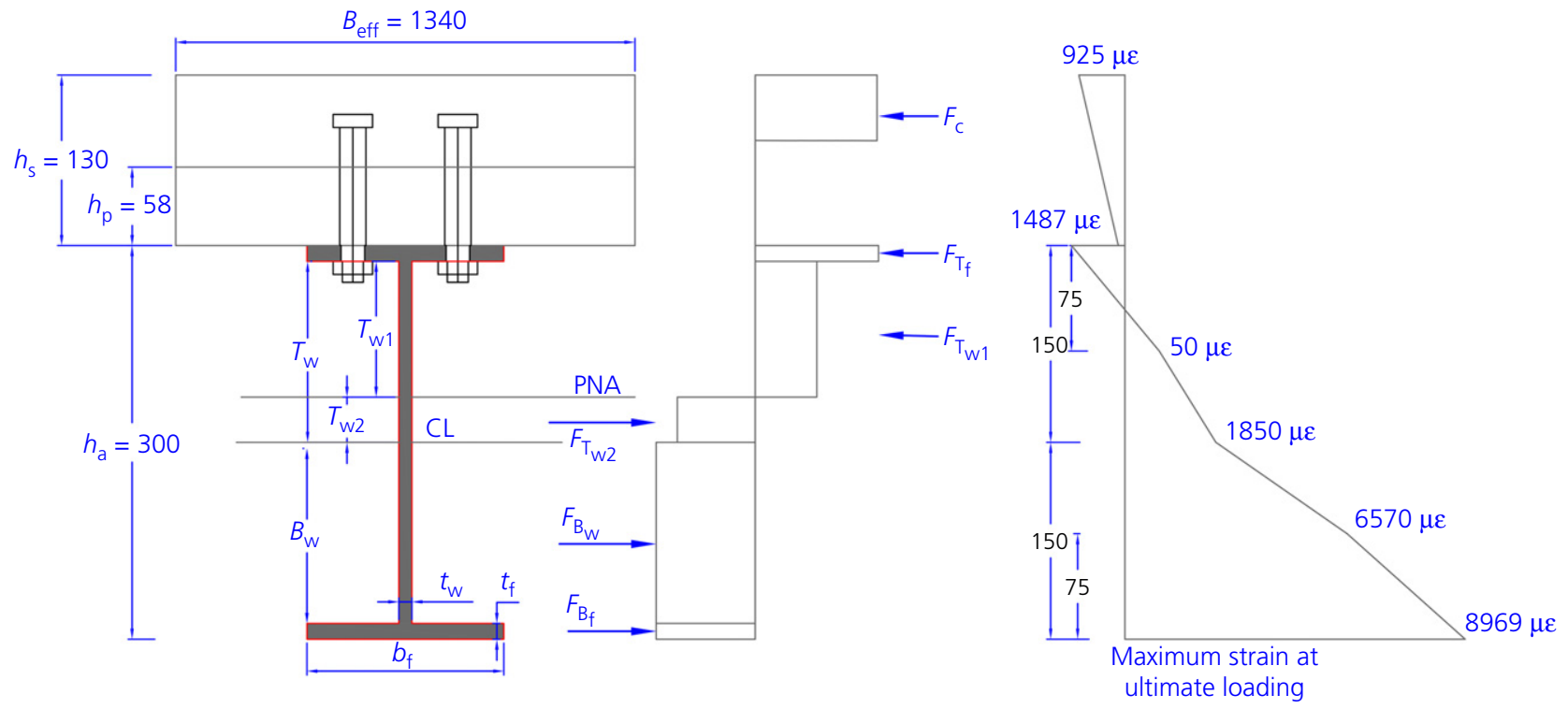

Figure 17. Rectangular stress block calculation model for ultimate moment capacity

Table 9. Comparison of ultimate moment capacities

\begin{tabular}{lcccc}
$\begin{array}{l}\text { Experimental, } \\
\boldsymbol{M}_{\text {uexp }}: \mathrm{kN} . \mathrm{m}\end{array}$ & $\begin{array}{c}\text { Stress block method, } \\
\boldsymbol{M}_{\mathrm{u}}: \mathrm{kN} . \mathrm{m}\end{array}$ & $\begin{array}{c}\text { Interpolation method, } \\
\boldsymbol{M}_{\text {Rd: }}: \mathbf{k N} . \mathbf{m}\end{array}$ & $\boldsymbol{M}_{\text {uexp }} / \boldsymbol{M}_{\mathbf{u}}$ & $\boldsymbol{M}_{\text {uexp }} / \boldsymbol{M}_{\text {Rd }}$ \\
\hline 323.50 & 318.80 & 308.2 & 1.01 & 1.05
\end{tabular}

14. $\delta_{\mathrm{c}}=\frac{P_{\mathrm{t}} a\left(3 l^{2}-4 a^{2}\right)}{24 E I_{\mathrm{comp}}}$

15. $\delta_{\mathrm{s}}=\frac{P_{\mathrm{t}} a\left(3 l^{2}-4 a^{2}\right)}{24 E I_{\mathrm{a}}}$

where $\delta_{\mathrm{s}}$ is the deflection of the steel beam acting alone, $\delta_{\mathrm{c}}$ is the deflection of the composite beam with full shear connection and $\eta$ is the degree of shear connection.

The predicted deflections using Equations 12 and 13 are presented in Table 10. The deflections predicted by Equation 13 are about $3 \%, 1 \%$ and $15 \%$ lower than the actual experimental values at $\mathrm{WL}, 1 \cdot 5 \mathrm{WL}$ and $3 \mathrm{WL}$, respectively. This shows that
BS 5950-3.1 (BSI, 2010) could be adopted with some modification for DCFSs.

\subsection{Demountability}

The DCFS was also evaluated for the purpose of demountability at the end of the test. To verify that the structural parts of the DCFS could be demounted and reused at the end of the design life, The DCFS was loaded up to its ultimate moment capacity and then unloaded. The nuts were checked at the end of the test; the nuts were all in place and no nut failure was observed. The nuts were easily demounted using an ordinary spanner.

After careful examination of the tested specimen, a fork-lift truck and crane were used to lift the whole composite slab off the steel beam. The composite concrete slab was completely lifted off the steel beam without any difficulty after the test, as

Table 10. Comparison of predicted deflection with experimental results

\begin{tabular}{|c|c|c|c|c|c|c|}
\hline Loading cycle & $P_{\mathrm{t}}: \mathrm{kN}$ & $\begin{array}{l}\text { Deflection predicted by } \\
\text { Equation } 12, \delta_{\mathrm{c}}: \mathrm{mm}\end{array}$ & $\begin{array}{l}\text { Deflection predicted by } \\
\text { Equation } 13, \delta_{\text {partial: }}: \mathrm{mm}\end{array}$ & $\delta_{\text {actual }}: \mathrm{mm}$ & $\delta_{\mathrm{c}} / \delta_{\text {actual }}$ & $\delta_{\text {partial }} / \delta_{\text {actual }}$ \\
\hline C1-C4 & $18 \cdot 12$ & $1 \cdot 42$ & $2 \cdot 51$ & $2 \cdot 6$ & 0.54 & 0.97 \\
\hline $\mathrm{C} 5$ & $27 \cdot 20$ & $2 \cdot 14$ & $3 \cdot 75$ & $3 \cdot 8$ & 0.56 & 0.99 \\
\hline C6 & $54 \cdot 50$ & $4 \cdot 28$ & $7 \cdot 49$ & 8.8 & 0.49 & 0.85 \\
\hline
\end{tabular}




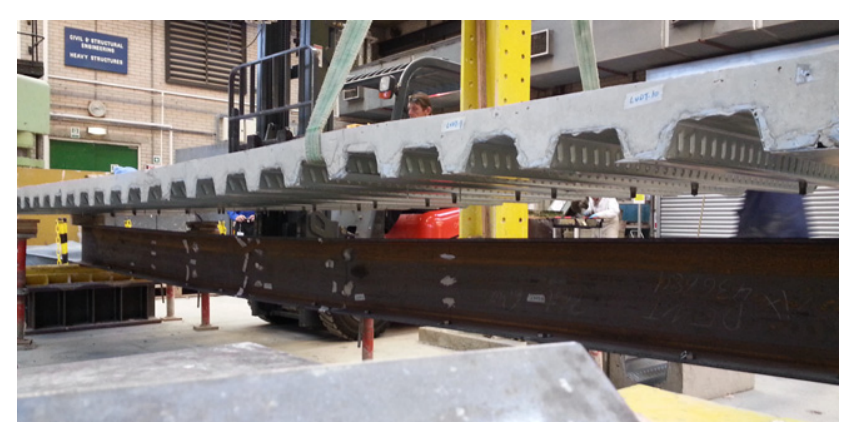

Figure 18. Demountability of specimen

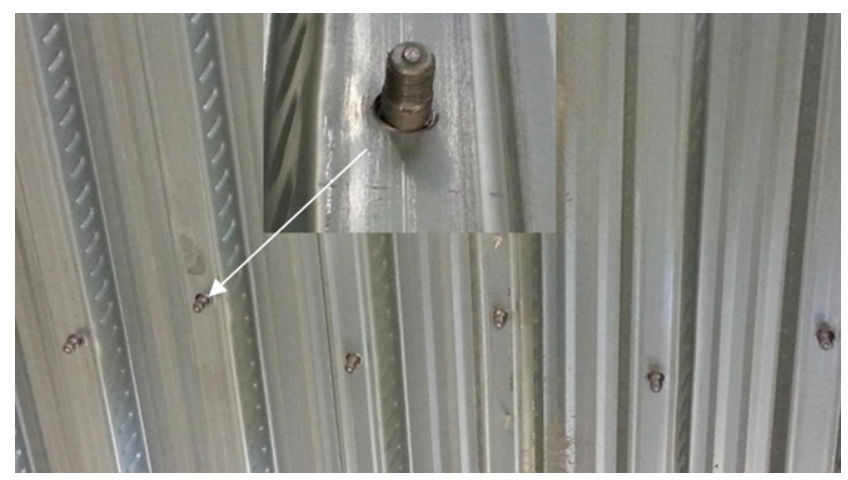

Figure 19. Connectors after demounting

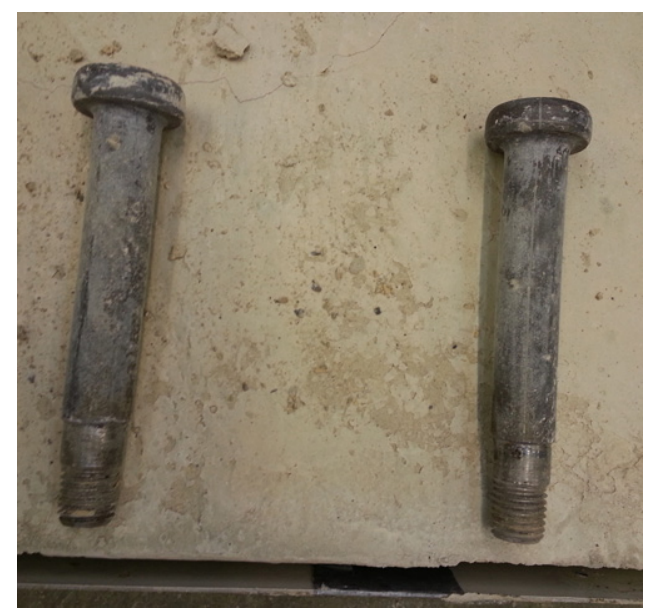

Figure 20. Demountable connectors after test

shown in Figure 18. There was no major damage to the collar or threaded part of the shear connectors, as can be seen in Figures 19 and 20. The experiment thus demonstrated that the proposed composite floor system using demountable shear connectors allows demounting of a composite slab from a steel section, even for a specimen loaded to its ultimate capacity.
The proposed floor system therefore has the potential to be used in sustainable composite construction. This DCFS will allow steel beams and precast composite concrete slabs to be reused after the structural design life without going into the recycling process.

\section{Conclusion}

Full-scale composite beam systems using demountable shear connectors and conventional welded shear connectors were tested to compare their load-bearing capacity and deconstructability. According to the comparison and analysis, the following conclusions may be made.

- The structural behaviour of the demountable composite floor system (DCFS) was very similar to that of the composite beam system with conventional welded shear connectors. The DCFS showed higher ductility although the initial stiffness was lower. This low initial stiffness might be a result of the oversized hole in the steel flange, which caused a larger initial slip between the steel beam and the composite slab. However, it might be possible to increase the stiffness by increasing the tightening force of the demountable connectors using a higher torque.

- The deflection of the DCFS specimen at three times the normal working load was about span/500, without any yielding of the steel beam section.

- The ultimate moment capacity of the demountable composite floor predicted by plastic theory was very close (only about 1\% lower) to the experimental results.

- BS 5950-3.1 (BSI, 2010) could be used to predict the deflection of demountable composite structures.

- Composite beams with demountable shear connectors can be demounted and reused successfully after service loading. The proposed floor system has the potential to be used in sustainable composite construction. It represents a smart solution for the construction of new composite slabs, with the aim of reusing the materials after their first use.

\section{REFERENCES}

BSI (2010) BS 5950-3.1:1990+A1:2010: Design in composite construction. Part 3: structural use of steelwork in building. BSI, London, UK.

CEN (Comité Européen de Normalisation) (2004) BS EN 1994-1-1: Eurocode 4: Design of composite steel and concrete structures. Part 1-1: General rules and rules for buildings. CEN, Brussels, Belgium.

Dai XH, Lam D and Saveri E (2015) Effect of concrete strength and stud collar size to shear capacity of demountable shear connectors. Journal of Structural Engineering 141(11): 04015025.

Dallam LN (1968) High strength bolt shear connectors - pushout tests. ACI Journal 65(9): 767-769.

Kwon G, Engelhardt M and Klingner R (2010) Behaviour of postinstalled shear connectors under static and fatigue loading. Journal of Constructional Steel Research 66(4): 532-541.

Lam D and Saveri E (2012) Shear capacity of demountable shear connectors. Proceedings of 10th International Conference on Advances in Steel Concrete Composite and Hybrid Structures, 
Singapore (Liew JYR and Lee SC (eds)). Research Publishing Services, Singapore, pp. 767-774.

Marshall WT, Nelson HM and Banerjee HK (1971) An experimental study of the use of high strength friction grip bolts as shear connectors in composite beam. The Structural Engineer 49(4): 171-178.

Mirza O, Uy B and Patel N (2010) Behavior and strength of shear connectors utilising blind bolting. Proceedings of 4th International Conference on Steel and Composite Structures (Uy B, Tao Z, Mashiri F, Zhu X, Mirza O and Tan EL (eds)). Research Publishing, Singapore, pp. 791-796.
Moynihan MC and Allwood JM (2014) Viability and performance of demountable composite connectors. Journal of Constructional Steel Research 99: 47-56, https://doi.org/10.1016/ j.jcsr.2014.03.008.

Rehman N, Lam D, Dai X and Ashour A (2016) Experimental study on demountable shear connectors in composite slabs with profiled decking. Journal of Constructional Steel Research 122: 178-189, https://doi.org/10.1016/j.jcsr.2016.03.021.

Schaap B (2004) Methods to Develop Composite Action in Non-Composite Bridge Floor Systems. MS thesis, The University of Texas, Austin, TX, USA

\section{How can you contribute?}

To discuss this paper, please email up to 500 words to the editor at journals@ice.org.uk. Your contribution will be forwarded to the author(s) for a reply and, if considered appropriate by the editorial board, it will be published as discussion in a future issue of the journal.

Proceedings journals rely entirely on contributions from the civil engineering profession (and allied disciplines). Information about how to submit your paper online is available at www.icevirtuallibrary.com/page/authors, where you will also find detailed author guidelines. 